\title{
On high interest rates in Brazil
}

FRANCISCO LAFAIETE LOPES*

This article examines the question of why interest rates are so high in Brazil as compared to the international average. It looks at theoretical arguments based on excessive government deficits, structural lack of private savings, inflation bias, excessive investment demand and fear of floating. An informal look at the evidence does not strongly corroborate any of these arguments. Hence a wise central bank should consider "testing" the market to make sure it is not dealing with an extreme equilibrium configuration or a long standing disequilibrium.

Keywords: interest rate; exchange rate; Brazilian economy.

JEL Classification: E43; F41; O11.

Brazil overcome open chronic inflation almost twenty years ago but could not get rid of high interest rates and overvalued exchange rates over this whole time period. Government has recently made attempts to lead the economy into a more "normal" configuration for these key macroeconomic variables. Many experts thought this was bound to fail. According to their view, real equilibrium values cannot be changed by naïve policy voluntarism without deeper, structural changes. This paper is an attempt to sort out the theoretical arguments relevant to this issue.

\section{A SIMPLE MACRO MODEL}

We use a simple two equations keynesian model, as in Lopes (2011). The first equation is the macroeconomic equilibrium of savings and investment. Savings is the sum of three components: private savings (SP), government savings $(\mathrm{SG})$ and external savings (SX); hence:

\footnotetext{
Francisco L. Lopes is partner at Macrometrica. E-mail: chlopes@macrometrica.com.br. Helpful comments from Pérsio Arida, Edmar Bacha and Rogério Werneck are gratefully acknowledged. Submitted: 24/June/2013; Approved: 16/August/2013.
} 


$$
\mathrm{I}(\mathrm{r})=\mathrm{SP}(\mathrm{u})+\mathrm{SG}+\mathrm{SX}(\mathrm{e})
$$

with derivatives: I'<0, SP' $>0, \mathrm{SX}^{\prime}<0$.

In this equation investment is inversely related to the real interest rate and private savings is positively related to capacity utilization. ${ }^{1}$ Government savings is measured by the sum of public sector fiscal surplus and public investment. External savings, which are inversely related to the real exchange rate, is the excess of imports over exports of goods and services, i.e., the current account deficit minus interest payments, profits and dividends (i.e., minus net income sent abroad). The equation defines a positive relationship between real exchange rate and real interest rate, which corresponds to the IS line in Figure 1.

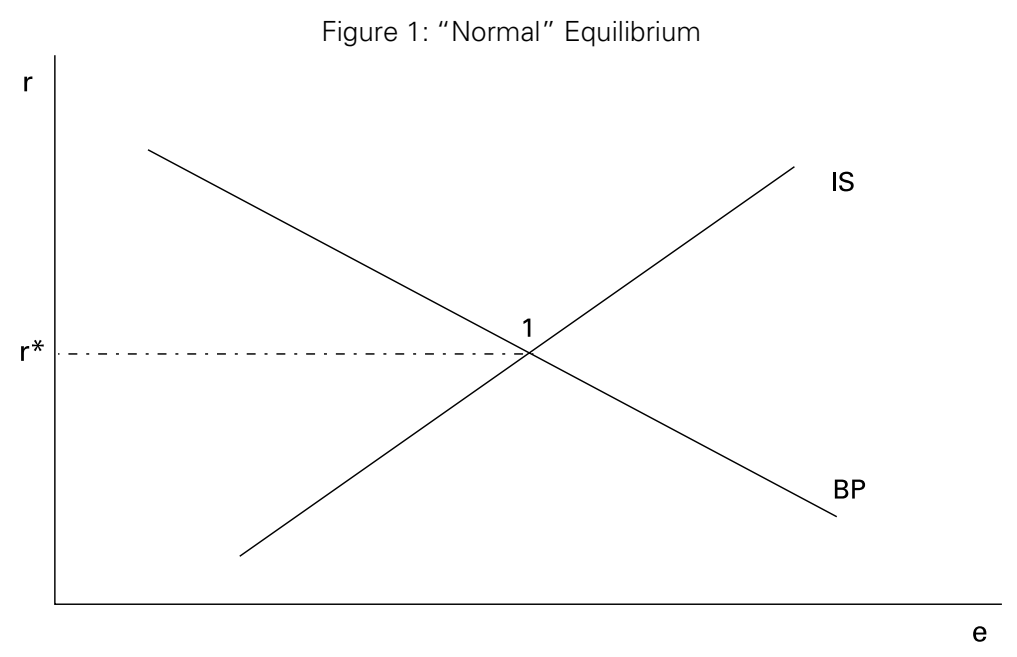

The second equation is the balance of payments equilibrium:

$\mathrm{SX}(\mathrm{e})=\mathrm{FX}(\mathrm{r})-\mathrm{DR}$

with derivatives: $\mathrm{SX}^{\prime}<0, \mathrm{FX}_{\mathrm{r}}>0$. The parameter $\mathrm{DR}$ is the absolute change in the international reserve position of the Central Bank.

The equation states that foreign savings equals net external financing ${ }^{2}$ (FX) minus the change in international reserves (DR). With free-floating exchange rates, the Central Bank does not operate in the foreign currency market and its reserve position remains fixed, i.e., $\mathrm{DR}=0$. Hence external savings and the real exchange rate are fully determined by the amount of external financing, which is positively related to the real interest rate. The equation defines an inverse relationship between real exchange rate and real interest rate as in the BP line in Figure 1.

We want to do some comparative static exercises dealing with inflationary equilibrium positions, that is, with configurations of the macro economy in which

\footnotetext{
${ }^{1}$ For the purpose of simplifying the exposition, we ignore the fact that private savings may also be a positive function of the interest rate.

${ }^{2}$ To ensure accounting consistency this net external financing must be defined as the surplus in the capital and financial account, plus errors and omissions and minus net income sent overseas.
} 
the level of capacity utilization is just right to keep the inflation rate constant over time. For a given value of this natural rate of activity, our two equations determine equilibrium values for the interest rate $(r)$ and the exchange rate (e). Let point 1 of Figure 1 be the equilibrium position in which the real interest rate is equal to an international average $\left(\mathrm{r}^{*}\right)$. We may call this the "normal" interest rate and use it as a sort of benchmark. The main purpose of this paper is to evaluate the rationale behind some common arguments that claim that in inflation equilibrium the Brazilian economy must have a real interest rate greater than this benchmark.

\section{GOVERNMENT DEFICIT}

The most frequent argument is that the equilibrium interest rate is high because our government deficit is too big. A large deficit means reduced government savings. This shifts the IS line to the left in Figure 1, producing a new equilibrium as in point 2 of Figure 2 below, with a higher real interest rate and a lower, more appreciated real exchange rate.

A low level of public savings means that, ceteris paribus, when capacity utilization is at the natural level in the inflation equilibrium, savings will not be enough to finance the investment demand that will result from the normal benchmark real interest rate. The economy would be permanently generating an excess demand for goods that would destroy the equilibrium. In order to avoid it, the Central Bank under an inflation target regime will be forced to raise the interest rate to the level of point 2 in Figure 2. At this higher level there will be more external financing and balance of payments equilibrium will require a larger volume of foreign savings, hence a larger deficit in the current account. A more appreciated exchange rate will be needed to achieve this.

Figure 2: Low Savings Equilibrium

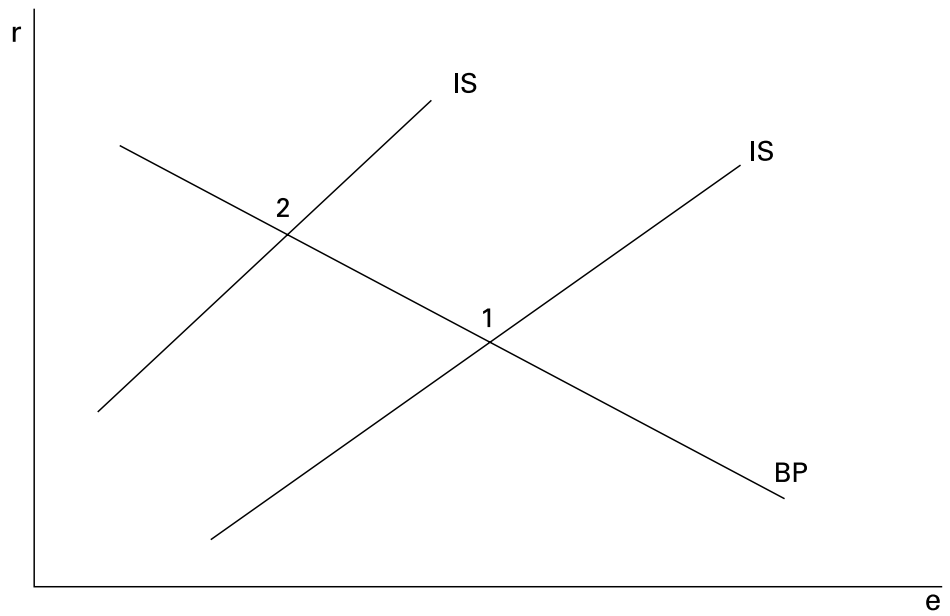


The obvious economic policy recommendation following from this argument is that we need a fiscal adjustment to increase public savings. This would shift the IS curve back to a position consistent with normal equilibrium in point 1.

The problem with this line of reasoning is that the Government deficit in Brazil is now clearly smaller than in most countries, including emerging ones, and all of them have much smaller real interest rates.

\section{PRIVATE SAVINGS}

An alternative explanation points to a deficient supply of private savings. If capacity utilization at the natural level produces a volume of private savings that is not enough for the investment demand generated at the normal interest rate, the interest rate will need to be higher. As in the previous case the equilibrium position will again be something like point 2 of Figure 2, with a higher real interest rate and a lower, more appreciated, real exchange rate.

But why is there a shortage of private savings? One "sociological" explanation is that cultural factors produce a lower average propensity to save in Brazil. This, however, does not fit well with the observation that interest rates close to the benchmark can be found in all sorts of countries with lots of cultural diversity, including some of our neighbors in Latin America.

A more sophisticated explanation, presented by Lara Resende (2011), uses the concept of jurisdictional uncertainty introduced by Arida et al. (2004). This uncertainty would be a consequence of decades of chronic inflation in which long-term financial savings in national currency have been systematically punished by arbitrary Government interventions. This, however, explains only the shape of the yield curve. The fact that long-term savings are discouraged is not relevant for the total volume of savings. Quite on the contrary: there should be a strong stimulus for financial savings in Brazil as anyone can get high yields with assets that are both very liquid and very secure, such as the Federal Government overnight floating-rate bonds (LFTs).

It is true that greater jurisdictional uncertainty may affect financial management decisions by relatively more sophisticated individuals leading them to shift their wealth into foreign assets. This, however, does not change the volume of private savings as defined in the national accounts. It would rather be shown in our model as a reduction, ceteris paribus, in net external financing (FX). Hence we would not have a shift to the left in the IS line, but rather a shift to the right in the BP line. This would lead to an equilibrium position with a higher real interest rate and also with a higher, more depreciated real exchange rate. Yet we may ignore this possibility as the position of the BP line can always be directly fixed by Central Bank through buying or selling of international reserves.

The best possible argument for explaining high interest rate as a consequence of a lack of private savings is in fact a variant of the fiscal explanation of the previous section. It relies on the observation that private savings depends not on total 
income but on the disposable income of the private sector, that is, total income less taxes. In terms of our model this means that private savings, in addition to being positively related to capacity utilization, must also be inversely related to the tax burden. So even though our Government deficit is comparable to that of other countries, our private savings are too small because of the tax burden. This could certainly explain an equilibrium interest rate above normal.

What is the evidence for the tax burden in Brazil? IBGE reports that the average burden between 2005 and 2009 was around 34\%. This puts us more or less at the OECD average, better than countries such as Germany, England, Portugal, Israel, France, Sweden, Denmark, Belgium, Austria, Italy, Hungary and the Netherlands. On the other hand we are worse than advanced countries such as United States and Korea, or even emerging countries such as Mexico and Chile. Since our real interest rate is greater than in all of these countries, the evidence seems quite inconclusive.

Another important consideration is that in order to define the concept of disposable income we should rather look at the net tax burden. Private savings depends on total income, including any type of transfer from the public sector to the private sector, minus taxes. IBGE defines this disposable income by subtracting from gross income the total of income taxes, rates and contributions and adding the total of grants, benefits and transfers to non-profit institutions.

It would, perhaps, be the case of asking whether the payment of interest on Government debt held by the public should not also be included as a sort of transfer affecting private savings. Suppose, for example, that Government increases taxes while also increasing by an equal amount the interest payments on debt held by households. It seems reasonable to assume that in this case aggregate savings by households will not be affected.

By IBGE's definition the average net tax burden was around $19.5 \%$ between 2005 and 2009. If we also exclude interest payments this number falls to around $14 \%$. If we look for equivalent numbers for other countries, it seems that our position is even better than in the case of gross debt. An economy with a heavy gross tax burden that also spends a large amount on transfers - that is to say, where the public sector is a big player in redistributing income through transfers - may have, ceteris paribus, the same private savings rate, and therefore the same real interest rate, as an economy with low tax burden and a smaller volume of transfers.

There is another line of argument, proposed by Rogério Werneck, which is based on the classic Haavelmo theorem on the balanced budget multiplier. This theorem shows that an increase in public expenditure has impact on the level of activity even when the deficit remains constant. In the last fifteen years primary spending in Brazil (i.e., excluding interest) rose by about 5 percentage points of GDP. So, even if the current level of spending is still compatible with the OECD average, its continued increase over a long period of time may have produced a series of demand shocks with the same effect on the real interest rate that would result from a structural deficiency of private savings. This would produce a shift to the left of the curve IS. We must understand, however, that this is a disequilibrium 
result that has no relevance for the equilibrium interest rate. It will cease to operate as soon as primary spending as a percentage of GDP stabilizes.

\section{INFLATION BIAS}

An alternative explanation assumes what we could call an inflation bias. This may result either from a sequence of inflationary shocks, or from destabilizing expectations fed by memories of chronic inflation, or from surviving over-indexation mechanisms. One example of this is the current rule for the annual minimum wage change, which adds past inflation to past GDP growth, and has an impact similar to the " $100 \%$ plus indexation" of Modigliani and Padoa-Schioppa (1977). This reduces the capacity utilization rate consistent with inflation equilibrium. The phenomenon manifests itself by the periodic need to reduce economic growth below potential in order to control inflation. The economy operates in a sort of inflation pseudo-equilibrium.

This notion of inflation bias has some subtlety. Its characterization in a comparative static analysis without explicit consideration of transition trajectories must be somewhat sketchy. As a matter of fact we can never effectively measure its strength in practice. Suppose the Phillips curve equation defining the inflation rate $(\mathrm{dp})$ is:

$$
\mathrm{dp}=\mathrm{f}(\mathrm{u})+(1+\mathrm{z}) \mathrm{dp}(-1)
$$

with $z>0$. Here this term " $z$ " captures the effect of over-indexation mechanisms and practices (the $100 \%$ plus indexation). It also captures the impact of possible destabilizing expectations resulting from a fortuitous combination of frequent inflationary shocks with a surviving inflation culture, which still exists as a legacy of relatively recent experiences with chronic inflation. The inflation equilibrium utilization rate $\mathrm{u}^{*}$ for the non-indexed economy, with $\mathrm{z}=0$, would be given by $f\left(u^{*}\right)=0$. The inflation equilibrium utilization rate for the inflation bias economy is given by $f\left(u_{o}\right)+z d p(-1)=0$. But since the normal utilization rate $u^{*}$ cannot be observed, we are unable to measure the differential $u^{*}-u_{\circ}$.

Evidence for this bias can be found in the long series of capacity utilization data built by Bacha and Bonelli in 2005 and now extended to 2010 (see Bacha \& Bonelli, 2012). From 1947 to 1981 the average utilization rate was $96.7 \%$ while from 1981 to 2010 it was $94.3 \%$. This reduction of 2 percentage points in the last two decades, which were plagued by chronic high inflation and several unsuccessful stabilization attempts, seems indeed consistent with the inflation bias hypothesis.

Since the inflation bias reduces the equilibrium capacity utilization rate it has the same impact on the position of the IS line as an autonomous reduction in savings. It shifts the equilibrium position to point 2 in Figure 2, with a higher real interest rate and a more appreciated real exchange rate. 


\section{INVESTMENT FUNCTION}

So far we have only dealt with explanations for high interest rates resulting from lack of aggregate savings. The problem, however, may be in the investment function. The savings function may be similar to the international benchmark while the investment function is not. Hence, with a normal real interest rate, total investment exceeds aggregate savings and the economy generates an excessive volume of demand. As in the case of insufficient savings, this also implies an IS line to the left of the benchmark, as in point 2 of Figure 2.

This case of excessive investment expenditures at the normal interest rate seems to be a quite relevant possibility in the case of an emerging economy, where the capital to labor ratio is relatively low and the marginal productivity of capital is relatively high. There are more investment opportunities than in a mature economy, hence with a normal interest rate there will be excess of demand in the equilibrium position.

In the Brazilian case, as has been emphasized by Pérsio Arida (2011), this effect can be further amplified by the action of official banks, such as the BNDES, supplying long-term credit at subsidized interest rates. We still lack a rigorous analysis of the impact of subsidized credit on the investment function, but we may learn something about it using a simple artificial example. Imagine there are only five available investment projects in the economy, all involving the same value of disbursement equal to $\mathrm{D}$. Therefore the maximum amount of investment is equal to 5D. The economic feasibility of each project depends on their internal rate of return. We assume these projects can be ordered according to their rates of return and that, when the Central Bank's interest rate is equal to $r$, these rates are equal to $r+2 x$, $\mathrm{r}+\mathrm{x}, \mathrm{r}, \mathrm{r}-\mathrm{y}, \mathrm{r}-2 \mathrm{y}$, where $\mathrm{x}$ and $\mathrm{y}$ are arbitrary values. In this case only the first three projects would be feasible and the total investment would be 3D.

Suppose now that the official bank grants subsidized loans only to the two most profitable projects. In this case the volume of subsidized investment would be $2 \mathrm{D}$, there would still be an amount $\mathrm{D}$ of unsubsidized investment and the two least profitable projects would still be unfeasible. Hence total investment would remain at the same level 3D that would occur if there was no subsidy. The only consequence of the subsidized loans would have been a fiscal transfer to the two most profitable projects.

The result is different if the official bank grants subsidized loans to the two least profitable projects. In this case the total volume of investment would increase to 5D, because the volume of non subsidized investment would still be 3D but we must add the amount 2D of subsidized investment that has become feasible as a consequence of the official loans. The conclusion is that subsidized credit increases total investment only if it turns unprofitable projects into profitable projects. Hence, if the goal of subsidized credit is to increase total investment it should be directed to low profitability projects, not to high profitability projects. Otherwise its only consequence will be to redistribute income from Government to private investors.

The conclusion is that subsidized loans directed toward high profitability proj- 
ects redistributes income without any impact on the equilibrium real interest rate, whereas subsidized loans directed toward low profitability projects tends to raise the demand for investment and, as a consequence, put upward pressure on the equilibrium interest rate.

\section{FEAR OF FLOATING}

We have seen that in equilibrium positions with high interest rate we often find an appreciated real exchange rate, as in point 2 in Figure 2. Assume Government does not want this appreciation, but is also not willing to deploy the fiscal adjustment needed to compensate for the insufficient supply of savings (or, perhaps, on the contrary, has an expansionary bias on its fiscal policy). Then its only alternative is to intervene in the foreign exchange market.

When the Central Bank operates as a buyer in the foreign exchange market the term DR becomes positive in the balance of payments equation. This shifts the BP curve to the right, leading the economy to a new equilibrium as in point 3 of Figure 3. In this case much of the currency appreciation that would occur in point 2 has been eliminated, but only at the cost of an additional increase in the interest rate. The attempt to avoid the exchange rate appreciation that would result from freefloating is therefore another possible explanation for an equilibrium interest rate above the international benchmark.

The strength of this effect increases when the exchange rate is not very sensitive to the interest rate, in the case where the IS line is almost vertical. The change in the interest rate between points 1 and 3 will be greater the lower the sensitivity of the exchange rate to the interest rate. Hence Government's attempt to avoid even a small currency appreciation may end up producing a large increase in the interest rate.

Figura 3: Equilibrium with Intervention

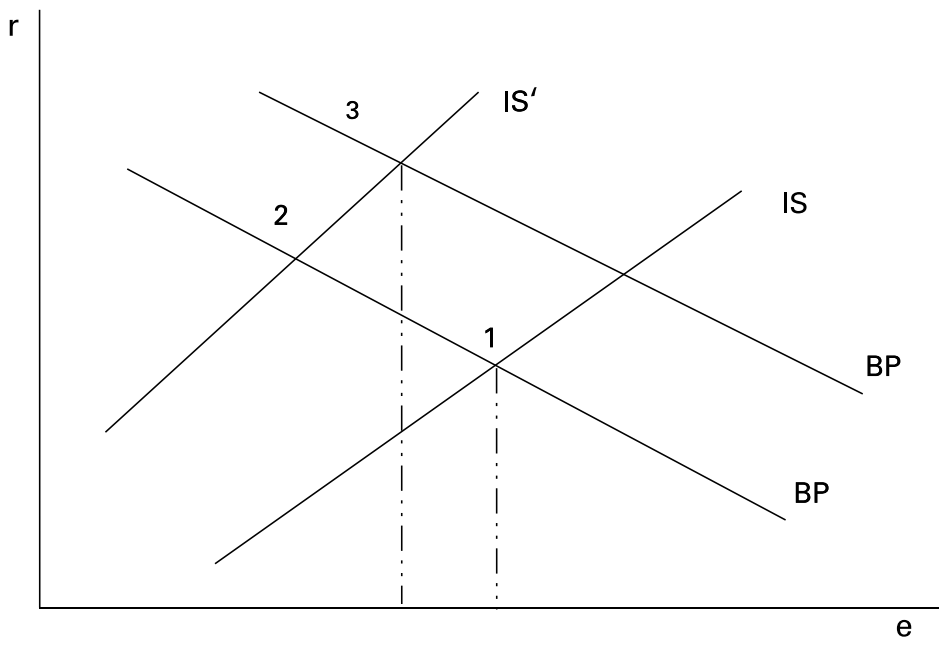


There are several factors that can justify the assumption of a strongly vertical IS line and that seem relevant for the Brazil. First, as pointed by Lopes (2011), the investment function itself may be to a large extent independent of the Selic rate as a result of our long experience with inflation and indexation mechanisms. An aggravating factor is that the BNDES supplies long-term loans with interest rates that are not sensitive to the Central Bank intervention rate. The problem here is not in the use of a subsidized rate, but in the use of a non-market based interest rate (the TJLP) which is fixed most of the time. The transmission of monetary policy would be stronger if BNDES worked with long term interest rates fixed by the market or at least with rates defined by some formula linked to the Selic.

Another factor that should be taken into account in determining the slope of the IS line is the sensitivity of Government savings to the interest rates. Government savings is equal to fiscal surplus plus Government investment. Since the payment of interest on the public debt held by the private sector reduces the fiscal surplus, we have an inverse relationship between Government savings and the real interest rate. This relationship offsets the interest rate sensitivity of the investment function producing an IS line with a slope closer to vertical.

By using the LFT, a bond with duration of just one day, the Brazilian Government actually strengthens this effect. In any country with public debt, Government savings are inversely related to the interest rate, but when this debt is mostly longterm the effect is usually small. In a country like Brazil, where an important part of public debt is in LFTs, the effect may be much higher.

There is still the theoretical possibility, suggested by Pérsio Arida, that private savings may be inversely related to the interest rate. When this rate decreases, private savings falls by the substitution effect, but rises by the income effect. It is conventional to assume that the substitution effect dominates the income effect, but this may not occur at a very high interest rate economy, such as Brazil. In extreme situations like this the income effect may dominate, which means that a reduction in the interest rate will reduce the present value of the financial wealth of the private sector. People will feel poorer, reducing their consumption and increasing their savings. Here, again, we have an inverse relationship between savings and interest rate that may offset the inverse relationship between investment and interest rate and generate a slope closer to vertical in the IS line.

\section{AN EXTREME CASE}

If an increase in the equilibrium interest rate always increases investment and private savings by the same amount, the line IS will be exactly vertical, but this is not the most surprising result we may generate in this simple model. An even more extreme case occurs when the interest rate has a stronger impact in savings than in investment. In this case, which cannot be excluded a priori, the IS line has an inverted slope. A reduction in equilibrium interest rate produces an increase in the exchange rate.

Figure 4 below reproduces the equivalent of our previous Figure 3 for this case. 
Point 1 is the desirable position in which interest rate equals the international benchmark and point 2 is an unwanted position with a higher interest rate and an over-valued exchange rate. To escape this position the Central Bank, which suffers from fear of floatin, buys foreign currency. As in the case of Figure 3 the result is an even higher interest rate. Surprisingly though, in this case the exchange rate is even more appreciated.

Figure 4: Exchange Intervention in an Extreme Case

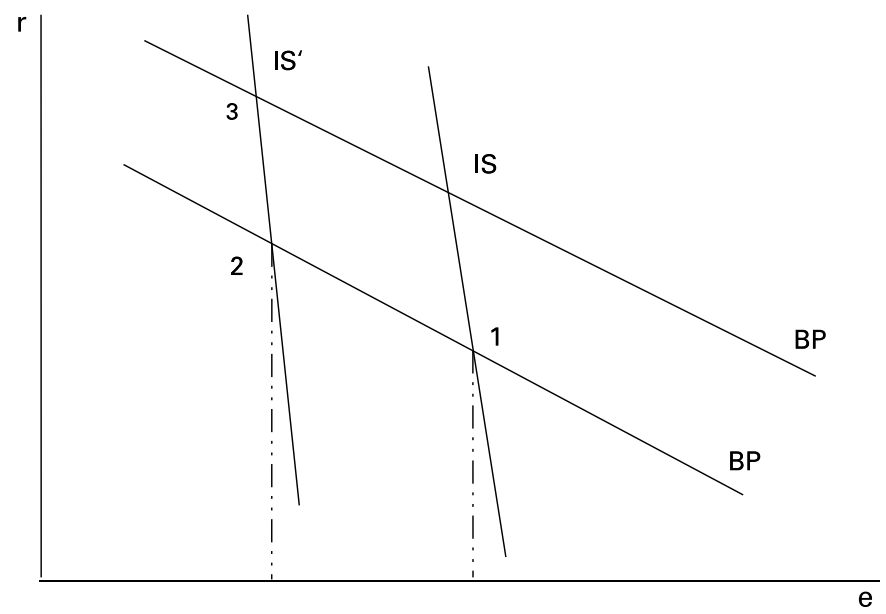

In order to understand the mechanics of this case it is helpful to restate the condition of macroeconomic equilibrium as the equality between foreign savings and the excess of investment over domestic savings, that is:

$$
\mathrm{I}(\mathrm{r})-\mathrm{SP}(\mathrm{u})-\mathrm{SG}(\mathrm{r})=\mathrm{SX}(\mathrm{e})
$$

with derivatives: I' $<0$, SP' $>0$, SG'< $<$ e SX' $<0$.

When the amount of savings by Government is inversely related to the interest rate and this effect outweighs the effect of this rate on investment, it follows that the excess of investment over private and public savings becomes positively related to the interest rate. Assuming that in the new equilibrium position of point 3 the interest rate is greater than in point 2 , we will also have in this position larger values for the excess of investment over domestic savings and for foreign savings. This will require an even more appreciated exchange rate.

\section{WHAT TO DO?}

Our analysis has shown that there are many possible explanations for an inflationary equilibrium with high interest rate and appreciated exchange rate. To the extent that this adequately reflects the current situation in the Brazilian economy, several policy recommendations follow logically. Actions that reduce Government deficit, stimulate private savings, reduce the tax burden, avoid inflation bias, reduce 
subsidized credit or allow free exchange rate fluctuation may all be useful in shifting the inflationary equilibrium towards a lower interest rate.

A positive agenda may also include measures designed to increase the effectiveness of the Selic rate, such as the introduction of greater flexibility in the TJLP or the complete elimination of LFTs. ${ }^{3}$

The economic policy problem, however, is a bit more complicated than this because in the real world we can never be sure that the economy is exactly in inflation equilibrium. It may be in disequilibrium for a huge amount of time. In addition, as pointed by Lopes (2011), when the Central Bank operates an inflation target regime there is no automatic convergence towards equilibrium, as it happens under a monetary target regime (à la Milton Friedman) or under a fixed exchange rate regime. In an inflation target regime the Central Bank has to operate the nominal interest rate in order to try to move the real interest rate towards the desired equilibrium position, but this real rate is endogenously determined by the economy.

Furthermore, when the exchange rate is not free to float we may have a persistent disequilibrium position of an almost permanent nature. This complicates a lot the problem of evaluating the actual position of the economy. In the typically case there is fear of floating. Government thinks that if it does not intervene in the currency market it will produce an unacceptable appreciation of the exchange rate. If this is the case it is advisable that the Central Bank should "test" the market in order to make sure it is not dealing with an extreme configuration such as that of Figure 4. It should also be willing to consider the possibility of an almost permanent disequilibrium configuration, as suggested in Lopes (2011). It could do this by checking whether small additional reductions in the interest rate produce only moderate and transitional disturbances in the inflation path.

\section{REFERENCES}

ARIDA, Pérsio, BACHA, Edmar \& LARA RESENDE, André (2004). "High Interest Rates in Brasil: Conjectures on the Jurisdictional Uncertainty". Inflation Targeting and Debt: the case of Brazil, MIT Press 2005

ARIDA, Pérsio (2011). "Crédito subsidiado impede queda dos juros: entrevista a Cristiano Romero", Valor Econômico, 13/12/2011.

BACHA, Edmar \& BONELLI, Regis (2005). “Uma Interpretação das Causas da Desaceleração Econômica do Brasil”. Revista de Economia Política, vol. 25, n. 3 (99), julho-setembro: 163-189. (2012). "Crescimento Brasileiro Revisitado", mimeo IEPE/CdG.

BACHA, Edmar \& BOLLE, Mônica, orgs. (2011). Novos Dilemas da Política Econômica, Rio de Janeiro: IEPE-LTC.

\footnotetext{
${ }^{3}$ Bacha (2011) puts forward the idea that the National Monetary Council (CMN) should, in the case of loans from Government banks, fix directly volumes and interest rates that are consistent with de monetary policy instance. This sort of "macroprudential" policy would be rather unconventional but could be very effective.
} 
BACHA, Edmar (2011). “Além da Tríade: Como Reduzir os Juros?”. In Edmar Bacha \& Mônica Bolle orgs. (2011): 130-139.

LARA RESENDE, André (2011). “A Armadilha Brasileira”, Texto para Discussão n 19, IEPE/CdG

LOPES, Francisco (2011). "A Estabilização Incompleta”. In Edmar Bacha \& Mônica Bolle, orgs. (2011): 116-129.

MODIGLIANI, Franco \& PADOA-SCHIOPPA, Tommaso (1978). "The Management of an Open Economy with ' $100 \%$ Plus' Indexation”. Essays in International Finance n. 130, Princeton University, Dec. 1978. 